\title{
Penguatan Kapasitas Kelembagaan dalam Pembangunan Kelurahan Berkelanjutan Berbasis Agrowisata di Kumpulrejo, Kota Salatiga
}

\section{Rahayu Rafikahwulan Sari ${ }^{1}$}

Fakultas IImu Sosial dan IImu Komunikasi, Universitas Kristen Satya Wacana, Salatiga, Indonesia

\section{Royke Robert Siahainenia}

Fakultas IImu Sosial dan IImu Komunikasi, Universitas Kristen Satya Wacana, Salatiga, Indonesia

\section{Suryo Sakti Hadiwijoyo}

Fakultas IImu Sosial dan IImu Komunikasi, Universitas Kristen Satya Wacana, Salatiga, Indonesia

Artikel Masuk : 29 Juni 2020

Artikel Diterima : 29 Agustus 2020

Tersedia Online : 31 Agustus 2020

\begin{abstract}
Abstrak: Kelurahan Kumpulrejo menjadi prioritas Kota Salatiga dalam pembangunan kelurahan berkelanjutan berbasis potensi lokal agrowisata. Kumpulrejo memiliki potensi di bidang peternakan. Hampir $80 \%$ penduduknya merupakan peternak sapi perah. Kapasitas kelembagaan Kelompok Tani Ternak (KTT) yang belum maksimal dalam mengelola potensi, menjadi masalah tersendiri dalam terciptanya pembangunan kelurahan berkelanjutan di Kumpulrejo. Modal sosial masyarakat diharapkan mampu memberikan pengaruh signifikan terhadap penguatan kapasitas kelembagaan KTT. Penelitian ini bertujuan untuk menganalisis pengaruh modal sosial terhadap penguatan kapasitas kelembagaan dalam pembangunan kelurahan berkelanjutan berbasis agrowisata di Kelurahan Kumpulrejo. Metode yang digunakan adalah deskriptif kuantitatif dengan menggunakan analisis regresi linier berganda. Data diperoleh dari kuesioner, observasi, dan wawancara. Teknik pengambilan sampel dilakukan secara acak sederhana berjumlah 60 responden. Hasil penelitian menunjukkan bahwa modal sosial berupa kepercayaan, jejaring sosial, dan norma memberikan pengaruh signifikan terhadap penguatan kapasitas kelembagaan sebesar 57,9\%. Secara parsial, kepercayaan memiliki pengaruh yang tidak signifikan, namun jejaring sosial dan norma memiliki pengaruh signifikan terhadap kapasitas kelembagaan KTT di Kelurahan Kumpulrejo.
\end{abstract}

Kata Kunci: kelompok tani ternak; modal sosial; penguatan kapasitas kelembagaan; pembangunan kelurahan berkelanjutan

Abstract: Kumpulrejo Village becomes the priority of Salatiga City in the sustainable village development based on the local potential of agrotourism. Kumpulrejo holds potential in livestock farming. Nearly $80 \%$ of the population are dairy farmers. The institutional capacity

\footnotetext{
${ }^{1}$ Korespondensi Penulis : Fakultas Ilmu Sosial dan Ilmu Komunikasi, Universitas Kristen Satya Wacana, Salatiga, Indonesia Email : rahayurafika12@gmail.com
} 
of the Livestock Farmers Group (KTT), which has not yet been maximized in managing potential, has become a particular problem in the creation of sustainable urban village development in Kumpulrejo. Community social capital is expected to have a significant influence on strengthening the institutional capacity of the KTT. This study aims to analyze the effect of social capital on strengthening institutional capacity in agrotourism-based sustainable urban village development in Kumpulrejo Village. This study used a descriptivequantitative approach and conducted a multiple linear regression. Data were obtained from questionnaires, observation, and interview. The sampling technique used simple random sampling, to 60 respondents. The study showed that social capital which consist of a trust, social network, and norms significantly affect to the institutional capacity strengthening by 57,9\%. Partially, a trust did not hold significantly affect, while social network and norms significantly affect the institutional capacity of livestock farmer groups in Kumpulrejo Village.

Keywords: livestock farmer groups; social capital; strengthening institutional capacity; sustainable village development

\section{Pendahuluan}

Pembangunan berkelanjutan menjadi agenda global yang harus diikuti oleh setiap negara, termasuk Indonesia. Sebagaimana tertuang dalam Peraturan Presiden Nomor 59 Tahun 2017 tentang Pedoman Pelaksanaan Tujuan Pembangunan Berkelanjutan, bahwa upaya pencapaian Tujuan Pembangunan Berkelanjutan (TPB) akan lebih efektif apabila dimulai dari tingkat basis, baik itu kelurahan atau desa maupun komunitas. Oleh karena itu, setiap daerah diharuskan untuk melakukan pembangunan yang bedasar TPB, akan tetapi memiliki kebebasan untuk menerapkan asas pembangunan berkelanjutan sesuai dengan kondisi dan potensi daerahnya masing-masing.

Penerapan TPB harus diikuti dengan kemampuan dan pengetahuan masyarakat dalam mengelola kelembagaan yang ada. Menurut Hadiwijoyo \& Anisa (2019), salah satu faktor penting dalam pencapaian pembangunan berkelanjutan adalah kelembagaan. Kekuatan dan kualitas lembaga akan mendukung tercapainya pembangunan yang berkelanjutan. Hal tersebut sesuai dengan poin ke 16 dalam TPB yaitu menguatkan masyarakat yang inklusif dan damai, terwujudnya penegakan keadilan untuk semua, serta membangun institusi yang tangguh. Oleh karena itu, penguatan kapasitas kelembagaan menjadi suatu hal yang penting diperhatikan untuk meningkatkan kinerja tugas dan fungsi dari kelembagaan tersebut. Dalam memperkuat kapasitas kelembagaan, modal sosial berupa kepercayaan, jejaring sosial, dan norma dapat menjadi aset yang menimbulkan adanya keteraturan, menumbuhkan kepercayaan, dan kemampuan kerjasama yang kuat dalam suatu lembaga (Syahra, 2003). Perihal pembangunan berkelanjutan, modal sosial berperan penting dalam perkembangan suatu wilayah secara berkelanjutan.

Asas pembangunan berkelanjutan yang masih terhitung baru, memerlukan kajian lebih dalam bagi beberapa daerah di Indonesia, terlebih pada tingkatan yang lebih spesifik seperti kelurahan, salah satunya adalah Kelurahan Kumpulrejo, Kota Salatiga. Kelurahan Kumpulrejo, Kecamatan Argomulyo, Kota Salatiga, saat ini sedang diarahkan menjadi kelurahan berkelanjutan yang berbasis pada potensi lokal agrowisata. Pembangunan kelurahan berkelanjutan sendiri merupakan salah satu upaya pemerintah daerah dalam mendukung pencapaian TPB yang dimulai dari tingkat basis, dengan langkah awal melakukan pemetaaan potensi dan permasalahan yang ada dalam wilayah tersebut. Selain itu, Kelurahan Kumpulrejo memiliki peran sebagai pendukung pencapaian Tri Fungsi Kota Salatiga, yaitu sebagai: (1) Kota Pendidikan dan Olahraga; (2) Transit Pariwisata; dan (3) Perdagangan dan Jasa. Sehubungan dengan hal tersebut, Kelurahan Kumpulrejo sebagai 
pendukung dua dari tiga fungsi yaitu fungsi transit wisata serta fungsi dalam perdagangan dan jasa berkaitan dengan potensi yang dimiliki.

Kelurahan Kumpulrejo, dianggap memiliki potensi yang terkait dengan pencapaian TPB, yaitu potensi agrowisata khususnya di bidang peternakan karena hampir $80 \%$ masyarakatnya bermatapencaharian sebagai peternak sapi perah. Populasi sapi perah di Kelurahan Kumpulrejo pada tahun 2018 tercatat mencapai 2.730 ekor (Dinas Pertanian Kota Salatiga, 2018). Angka tersebut lebih dari setengah populasi sapi perah yang ada di Kota Salatiga yaitu sebanyak 3.590 ekor pada tahun 2019, (BPS Kota Salatiga, 2020). Dari keseluruhan populasi sapi perah di Kelurahan Kumpulrejo, susu sapi yang diproduksi dapat mencapai 3.000 liter perhari. Sektor peternakan menjadi salah satu sumber daya yang sangat berpotensi untuk dikembangkan sebagai pendukung kelurahan agrowisata karena sifatnya yang dapat diperbaharui (Suyitman, Sutjahjo, Herison, \& Muladno, 2016). Dalam kerangka pembangunan, agrowisata secara luas dan sektor peternakan secara khusus memiliki peranan yang besar untuk menciptakan kemandirian pangan hewani yang berkualitas (Daryanto, 2009). Terlebih karena permintaan kebutuhan pangan yang semakin meningkat akibat pertumbuhan penduduk yang cenderung mengalami peningkatan di setiap tahunnya, maka sumber daya alternatif seperti sektor petenakan ini perlu dikembangkan, di samping itu pemanfaatan sumber daya alam yang dapat diperbaharui dapat menjadi salah satu sarana perlindungan terhadap lingkungan.

Dalam menjadikan Kumpulrejo sebagai kelurahan agrowisata, diperlukan kerjasama seluruh pemangku kepentingan, dalam hal ini Kelompok Tani Ternak (KTT) berperan sebagai aktor utama dalam pengembangan agrowisata di Kelurahan Kumpulrejo. Kelembagaan lokal seperti KTT berperan penting dalam mengelola potensi serta menjadi salah satu sarana kerjasama antarsesama peternak dalam kelompok, antarkelompok, maupun pemerintah, dan menjadi wadah bagi peternak untuk bergerak mengembangkan kemampuannya serta usahanya dalam mencapai tujuan bersama (Triambodo, 2015). Oleh karena itu, KTT memiliki andil yang cukup besar dalam mengembangkan agrowisata melalui pengembangan usaha ternak di Kelurahan Kumpulrejo.

Sehubungan dengan hal tersebut, peneliti menemukan permasalahan terkait upaya Kelurahan Kumpulrejo menjadi keluruhan agrowisata dengan memperoleh dukungan pemerintah daerah berupa bantuan sapi perah. Namun sapi perah yang seharusnya dikelola dan dipelihara secara berkelompok di kandang koloni yang telah disediakan oleh pemerintah, pada kenyataannya belum bisa dikembangkan sebagai salah satu syarat mengembangkan agrowisata. Hal tersebut menunjukkan bahwa, belum berkembangnya usaha tani ternak sebagai penopang utama agrowisata, salah satunya disebabkan belum tumbuhnya modal sosial di dalam pengembangan kapasitas kelembagaan kelompok tani.

Subekti, Sudarko, \& Sofia (2015), dalam penelitiannya menunjukkan hasil bahwa penguatan kelompok tani dapat tumbuh dengan cara mensinergikan hubungan yang terjalin antara kelompok tani dengan pemangku kepentinan lainnya yang ada dalam lingkungan sosial kelompok tani. Modal sosial sebagai aset yang dimiliki oleh masyarakat Kumpulrejo berperan penting dalam penguatan kapasitas kelembagaan KTT. Dalam konteks ini, hipotesis yang dibangun adalah seberapa besar pengaruh modal sosial yang dimiliki kelompok berupa kepercayaan, jejaring sosial, dan norma terhadap penguatan kapasitas kelembagaan. Modal sosial berupa kepercayaan akan menghasilkan penguatan kapasitas kelembagaan melalui transparan, bertanggunggjawab dan tingginya partisipasi individu dalam kelompok. Aktivitas kelompok juga memiliki keteraturan yang diikat oleh norma-norma sosial.. Norma juga sebagai hukum yang berlaku dalam kelompok, sehingga menjadikan kelompok berkerja secara lebih terorganisasi. Selanjutnya, akan terjalin pola hubungan kerjasama yang kuat dan mendapatkan hasil yang lebih optimal. Sebagaimana dikatakan oleh Fukuyama (1995) dan Kholifa (2016) menyatakan bahwa modal sosial yang lahir dan berkembang dalam suatu kelompok dengan dasar nilai dan norma yang disepakati 
bersama dapat memberikan kekuatan lebih dalam kelompok tersebut dan memiliki peran penting dalam penguatan kapasitas kelembagaan.

Penelitian Fitriani (2015), menunjukkan bahwa rendahnya kapasitas kelembagaan kelompok tani disebabkan karena kurangnya komunikasi dan koordinasi antaraanggota dan pengurus dalam kelembagaan kelompok tani. Seran \& Kote (2007) dalam penelitiannya menyatakan bahwa kelembagaan kelompok tani memiliki kesempatan untuk meningkatkan dan memperkuat kapasitasnya dengan berpartisipasi secara aktif dalam setiap kegiatan yang berkaitan dengan kebutuhannya. Penguatan kapasitas kelembagaan dimaksudkan sebagai proses peningkatan kemampuan yang dimiliki oleh setiap individu, organisasi, maupun sistem suatu kelembagaan.

Menurut Milen (2004), sebagai upaya pencapaian penguatan kapasitas kelembagaan maka harus difokuskan pada tiga tingkatan yaitu individual, organisasi, dan sistem. Dalam konteks tingkatan individu, yang dimaksud adalah pada pengembangan sumber daya manusia dalam kelembagaan, dengan perhatian diberikan pada profesionalitas dan kemampuan personil secara teknis seperti potensi yang dimiliki, keterampilan, attitude, kemampuan dalam pengelompokan pekerjaan, serta motivasi yang dimiliki individu. Dalam kaitannya dengan tingkatan organisasi, difokuskan pada manajemen untuk perbaikan kinerja dari fungsi dan tugas yang dilihat dari kelengkapan struktur, kesesuaian prosedur dan mekanisme pekerjaan, kejelasan proses pengambilan keputusan, pengaturan sarana prasarana, serta terjalinnya hubungan dan jaringan secara internal maupun eksternal. Selanjutnya, dalam konteks sistem, lebih dtekankan pada pengaturan struktur secara makro dengan melihat kerangka pekerjaan, kesesuaian peraturan dengan kebijakan, dan alasan pendukung objektivitas kebijakan dalam kelembagaan tersebut. Tiga tingkatan di atas merupakan parameter untuk mengukur nilai penguatan kapasitas kelembagaan, yang berarti semakin tinggi nilai tingkatan individual, tingkatan organisasi, menuju ke arah tingkatan sistem maka semakin kuat kelembagaan tersebut.

Berdasarkan uraian tersebut, modal sosial yang dimiliki oleh kelembagaan KTT secara teoritis dapat mendorong penguatan kapasitas kelembagaan tersebut. Namun beberapa penelitian belum membahas keterkaitan modal sosial dan penguatan kapasitas kelembagaan dengan asas tujuan pembangunan berkelanjutan khususnya di tingkat basis dengan mengedepankan potensi lokal yang dimiliki. Oleh karena itu, penelitian ini difokuskan untuk mengetahui pengaruh modal sosial terhadap penguatan kapasitas kelembagaan KTT dalam pembangunan kelurahan berkelanjutan berbasis agrowisata. Penelitian ini bertujuan untuk mengetahui pengaruh modal sosial terhadap penguatan kapasitas kelembagaan dalam pembangunan kelurahan berkelanjutan berbasis agrowisata di Kelurahan Kumpulrejo

\section{Metode Penelitian}

Metode yang digunakan adalah kuantitatif dengan pendekatan positivisme. Data primer dikumpulkan dengan penyebaran kuesioner. Kuesioner dalam penelitian ini berkaitan dengan identitas anggota, modal sosial, serta penguatan kapasitas kelembagaan KTT di Kelurahan Kumpulrejo. Item pernyataan dirancang berdasarkan model skala likert dengan pengukuran skala ordinal, dan disajikan dengan lima alternatif jawaban yaitu: (1) Sangat Tidak Setuju (STS); (2) Tidak Setuju (ST); (3) Netral (N); (4) Setuju; dan (5) Sangat Setuju (SS). Pengelolaan data dilakukan dengan tahap editing, coding, dan tabulating. Untuk mendukung hasil uji terhadap hipotesis juga dimungkinkan menggunakan data hasil interview dari pertanyaan yang dikembangkan dalam kuesioner. Populasi penelitian ini yaitu anggota aktif KTT berjumlah 299 anggota, sementara sampel penelitian yang diambil berjumlah $299 \times 20 \%=59,8$ dibulatkan menjadi 60. Penentuan sampel menggunakan metode simple random sampling, adapun identitas responden dapat dilihat pada Gambar 1. 


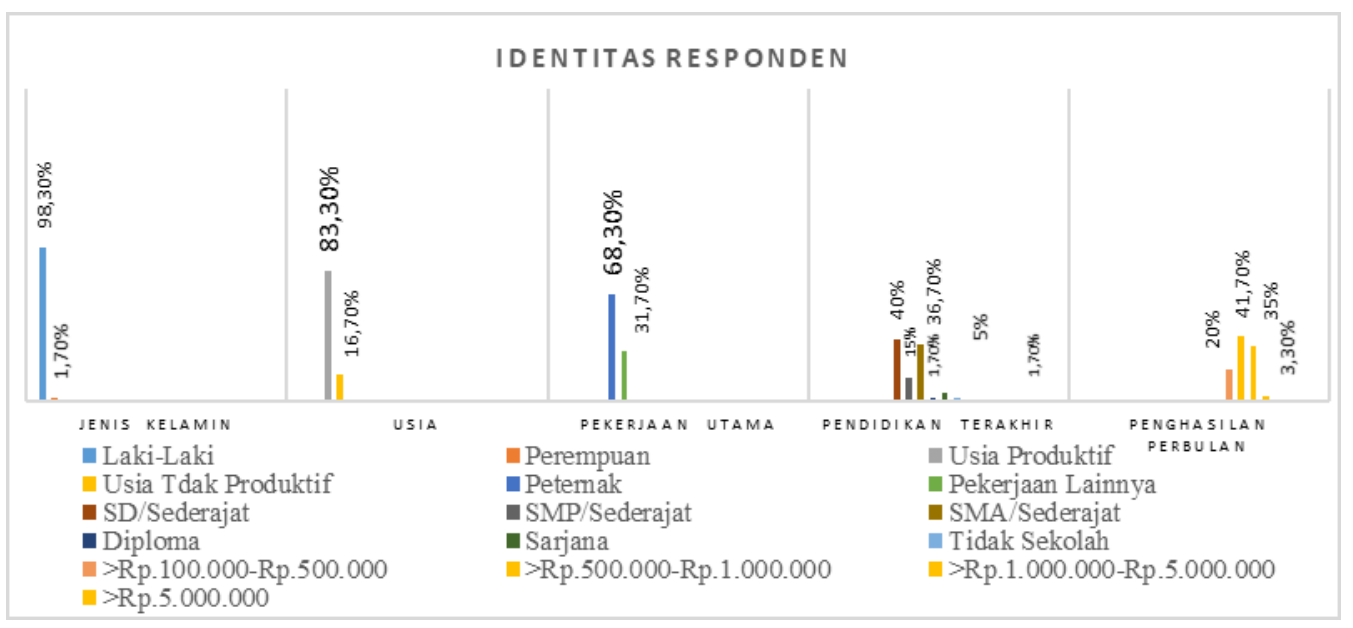

Gambar 1. Identitas Responden

Analisis data dilakukan dengan analisis regresi linier berganda dan disajikan secara deskriptif. Analisis deskriptif dilakukan dengan mengkategorisasikan masing-masing variabel dalam penelitian ini menggunakan persamaan (1), sebagai berikut.

$$
\begin{aligned}
& \text { Rendah }=\mathrm{X}<\text { Mean }-1 \text { Standar Deviasi } \\
& \text { Sedang }=\text { Mean }-1 \text { Standar Deviasi } \leq \mathrm{X}<\text { Mean }+1 \text { Standar Deviasi } \\
& \text { Tinggi }=\text { Mean }+1 \text { Standar Deviasi } \leq \mathrm{X}
\end{aligned}
$$

Fokus penelitian ini adalah melihat pengaruh modal sosial termasuk di dalamnya unsur kepercayaan, jejaring sosial, dan norma terhadap penguatan kapasitas kelembagaan KTT di Kelurahan Kumpulrejo. Adapun variabel penelitian dapat dilihat pada Tabel 1.

Tabel 1. Variabel Penelitian

\begin{tabular}{lll}
\hline \multicolumn{1}{c}{ Variabel } & \multicolumn{1}{c}{ Indikator Penilaian } & \multicolumn{1}{c}{ Sumber } \\
\cline { 2 - 3 } Kepercayaan $\left(\mathrm{X}_{1}\right)$ & $\begin{array}{l}\text { Kejujuran; Kewajaran; Sikap Egaliter Toleransi; } \\
\text { Kemurahan Hati }\end{array}$ & (Kadarisman, 2017; \\
Jejaring Sosial $\left(\mathrm{X}_{2}\right)$ & $\begin{array}{l}\text { Partisipasi; Resiprositas; Solidaritas; Kerjasama } \\
\text { (Kadarisman, 2004) }\end{array}$ & $\begin{array}{l}\text { Lawang, 2004) } \\
\text { Norma }\left(\mathrm{X}_{3}\right)\end{array}$ \\
& $\begin{array}{l}\text { Nilai-nilai Bersama; Norma dan Sanksi; Aturan- } \\
\text { aturan }\end{array}$ & (Kadarisman, 2017; \\
Penguatan Kapasitas & Tingkatan Individu; Tingakatan Organisasi; 2004) & (Milen, 2004; Rizki, 2015; \\
Kelembagaan $(\mathrm{Y})$ & Tingkatan Sistem & Soeprapto, 2006) \\
\hline
\end{tabular}

Sebagai prasyarat kelayakan instrumen, dilakukan uji validitas dan reliabilitas dengan menggunakan 30 responden. Hasil uji validitas dan reliabilitas menunjukkan bahwa seluruh instrumen penelitian valid dan reliabel, karena nilai $r_{\text {hitung }}$ seluruh instrumen lebih dari nilai

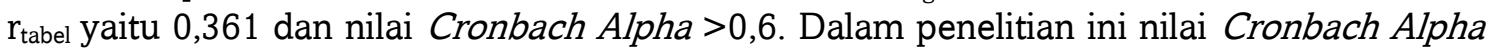
pada varibel kepercayaan sebesar 0,676 dengan kategori tinggi, variabel jejaring sosial sebesar 0,757 dengan kategori tinggi, variabel norma sebesar 0,657 dengan kategori tinggi, dan pada variabel penguatan kapasitas kelembagaan sebesar 0,941 dengan kategori sangat tinggi. Berdasarkan hasil uji validitas dan reliabilitas, instrumen penelitian dinyatakan layak untuk digunakan. Sebelum dianalisis, terlebih dahulu dilakukan uji asumsi klasik sebagai prasarat kelayakan data, dengan hasil sebagai ditampilkan pada Tabel 2. 
Tabel 2. Uji Asumsi Klasik Data Penelitian

\begin{tabular}{clll}
\hline No & \multicolumn{1}{c}{ Uji Prasarat } & \multicolumn{1}{c}{ Hasil } & Keterangan \\
\hline 1 & Normalitas & Kolmogorov-Smirnov Tes $t=0,067$ & Normal \\
2 & Linieritas & Sig.Dev from Linierity $=0,112$ & Linier \\
& $X_{1}$ terhadap Y & Sig.Dev from Linierity $=0,687$ & Linier \\
& $\mathrm{X}_{2}$ terhadap Y & Sig.Dev from Linierity $=0,112$ & Linier \\
& $\mathrm{X}_{3}$ terhadap Y & Tidak ada gejala \\
3 & Multikolinieritas & Tolerance $=0,857 ; \mathrm{VIF}=1,167$ & Tidak ada gejala \\
& Kepercayaan & Tolerance $=0,628 ; \mathrm{VIF}=1,593$ & Tidak ada gejala \\
& Jejaring Sosial & Tolerance $=0,616 ; \mathrm{VIF}=1,623$ & Tidak ada gejala \\
& Norma & Titik data plotting menyebar di atas dan di bawah & \\
4 & Heteroskedastisitas & nilai 0 pada sumbu Y, serta tidak membentuk pola & \\
& & apapun (Uji Scatterplot) & \\
\hline
\end{tabular}

Data yang terkumpul dianalisis dengan menggunakan analisis statistik regresi linier berganda dengan bantuan aplikasi software SPSS IBM Versi 25, dan disajikan secara deskriptif. Analisis regresi liner berganda dilakukan melalui pengujian terhadap hipotesis dengan tahap pertama mencari koefisien determinasi dengan menggunakan persamaan (2).

$$
R^{2} \frac{b_{1} \sum x_{1} y+b_{2} \sum x_{2} y+b_{3} \sum x_{3} y}{\sum Y^{2}}
$$

Keterangan: $R^{2}=$ koefisien determinasi; $b_{1}, b_{2}, b_{3}=$ koefisien kepercayaan, jejaring sosial, dan norma; $\sum x_{1} y \sum x_{2} y \sum \mathrm{x}_{3} y=$ Jumlah perkalian antar prediktor; $\sum \mathrm{Y}^{2}=$ Jumlah y kuadrat. Tahap kedua mencari sumbangan relatif (SR) yang bertujuan untuk mencari perbandingan relatifitas yang diberikan variabel independen kepada variabel dependen dengan menggunakan persamaan (3) dan sumbangan efektif yang bertujuan untuk mengetahui besarnya sumbangan secara mandiri pada setiap variabel yang kemudian dipersentasekan dengan menggunakan persamaan (4).

$$
S R(X) \%=\frac{S E(X) \%}{R^{2}}
$$

Keterangan: $S R \%=$ Sumbangan relatif dari suatu prediktor; $S E \%=$ Sumbangan efektif dari suatu prediktor; $\mathrm{R}^{2}=\mathrm{R}_{\text {Square }}$ atau koefisien determinasi.

$$
S E \%=S R \times R^{2}
$$

Keterangan: $S E \%=$ Sumbangan efektif dari suatu prediktor; $S R=$ Sumbangan relatif dari suatu prediktor; $R^{2}=$ Koefisien Determinasi. Tahap ketiga, yaitu melakukan Uji t parsial yang dilakukan untuk mengetahui pengaruh variabel bebas terhadap variabel terikat secara sendiri dengan melihat korelasi variabel bebas lainnya. Dengan ketentuan jika nilai Sig. $<0,05$ maka artinya variabel bebas memiliki pengaruh signifikan secara parsial terhadap variabel terikat. Tahap keempat, yaitu melakukan Uji F simultan bertujuan untuk mengetahui pengaruh antara variabel bebas secara bersama-sama terhadap variabel terikat. Dengan ketentuan jika nilai Sig. $<0,05$ maka artinya variabel bebas memiliki pengaruh secara simultan terhadap variabel terikat. 


\section{Hasil dan Pembahasan}

\section{Kondisi Geografis Wilayah}

Kelurahan Kumpulrejo berada di Kecamatan Argomulyo, Kota Salatiga, Provinsi Jawa Tengah. Secara geografis, Kelurahan Kumpulrejo memiliki letak yang strategis di bawah Gunung Merbabu dan Jalan Semarang Solo. Secara administratif berbatasan dengan Kelurahan Tegalrejo (sebelah Utara), Desa Somagawe (sebelah Barat), Desa Jetak Kecamatan Getasan (sebelah Selatan), dan Kelurahan Randuacir (sebelah Timur). Untuk menjalankan administrasi pemerintahan, Kelurahan Kumpulrejo dibantu oleh 10 Rukun Warga (RW) dan 43 Rukun Tetangga (RT). Berdasarkan data dari Lurah setempat, hampir 80\% masyarakat Kelurahan Kumpulrejo bermatapencaharian sebagai peternak sapi perah. Kelurahan Kumpulrejo memiliki 15 Kelompok Tani yang tersebar di seluruh dusun dan 13 di antaranya merupakan KTT dengan komoditas utama yaitu sapi perah. Lokasi Penelitian di Kelurahan Kumpulrejo dapat dilihat pada Gambar 2.

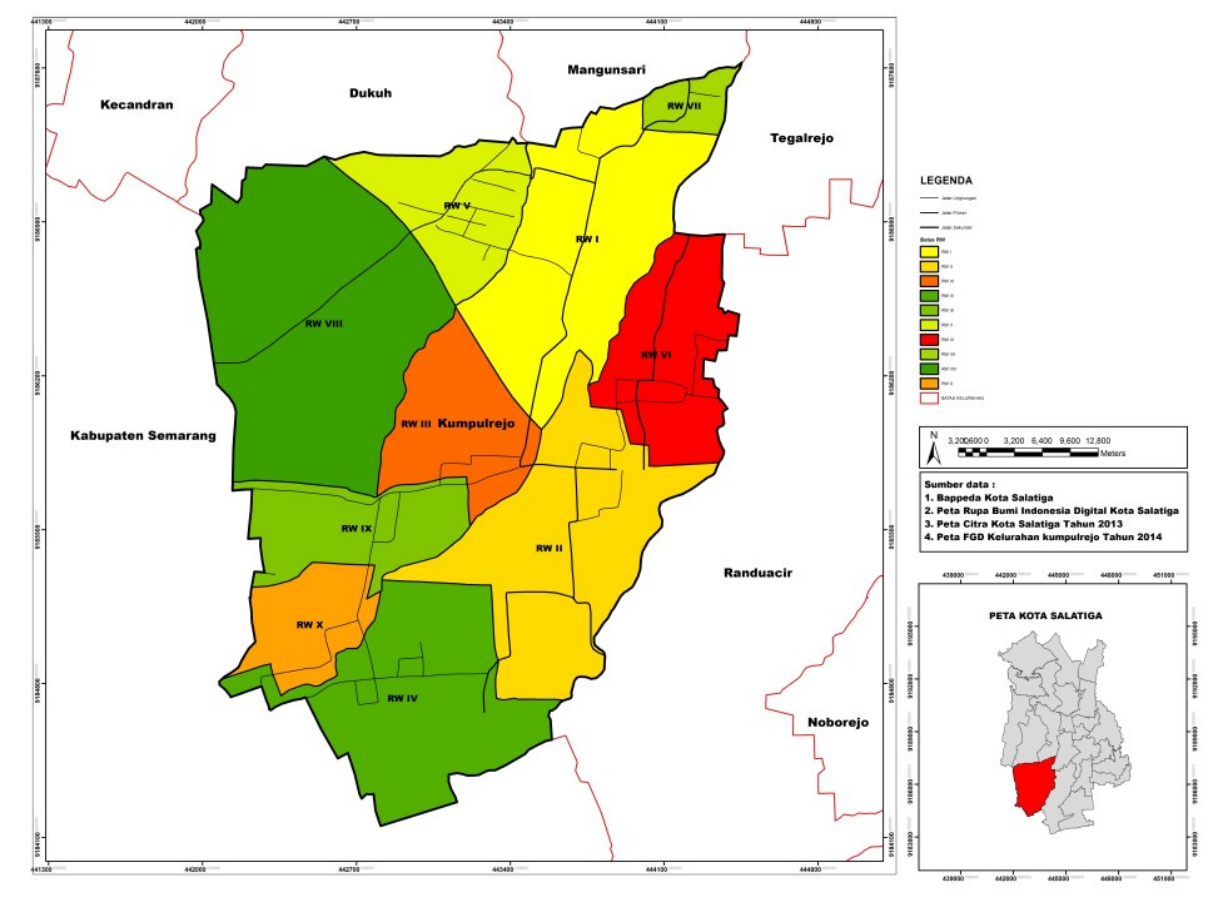

Gambar 2. Peta Kelurahan Kumpulrejo

\section{Pengaruh Kepercayaan terhadap Penguatan Kapasitas Kelembagaan KTT di Kelurahan Kumpulrejo}

Kepercayaan dalam sebuah kelompok menjadi dasar dari keberhasilan kelompok tersebut untuk mencapai tujuan bersama. Rasa percaya akan terjalin dengan adanya interaksi yang intens dan berkualitas. Adapun hasil analisis pengaruh kepercayaan terhadap penguatan kelembagaan KTT di Kelurahan Kumpulrejo dapat dilihat pada Tabel 3.

Tabel 3 menunjukkan hasil bahwa secara parsial diperoleh nilai koefisien regresi sebesar 0,075. Pada taraf signifikansi $5 \%$ diperoleh nilai $t_{\text {hitung }} 0,799$ dan nilai signifikansi sebesar 0,428, dikarenakan nilai signifikansi >0,05 maka kepercayaan memiliki pengaruh yang tidak signifikan terhadap penguatan kapasitas kelembagaan KTT di Kelurahan Kumpulrejo. Hasil analisis menunjukkan bahwa terdapat kecurigaan anggota kelompok 
kepada pengurus, yang disebabkan tidak adanya transparansi mengenai dana yang dikelola oleh pengurus, khususnya pemasukan dan pengeluaran dalam koperasi internal kelompok. Hal tersebut menunjukkan bahwa dalam pengelolaan kelembagaan KTT di Kelurahan Kumpulrejo belum sesuai dengan asas tata kelola yang baik berupa transparansi dan akuntabilitas. Sikap pengurus dalam mengelola kelompok menimbulkan adanya rasa curiga anggota yang berdampak pada berkurang atau bahkan menghilangnya kepercayaan anggota dalam KTT. Seperti halnya penelitian Gefen, Karahanna, \& Straub (2003), diungkapkan bahwa kepercayaan dalam suatu kelompok akan tumbuh jika terdapat dua unsur yaitu keyakinan memercayai dan ingin memercayai. Dalam hal ini, keyakinan ingin memercayai diartikan sebagai sifat yang dapat dipercaya yang merupakan persepsi anggota kelompok terhadap sesama anggota, terhadap pengurus, maupun terhadap kelompoknya. Sementara itu sikap ingin memercayai dapat diartikan sebagai sikap anggota kelompok bersedia untuk mempertahankan sesuatu yang ia percaya (Kim \& Benbasat, 2003; Simatupang, 2017). Dalam penelitian ini menunjukkan bahwa anggota KTT memiliki keyakinan yang kurang untuk memercayai pengurus karena pengelolaan kelompok yang kurang baik. Pratama, Muchammad, \& Djumiarti (2014), dalam penelitiannya menyebutkan bahwa dalam penguatan kapasitas kelembagaan sikap responsif dan saling terbuka antara pengurus dan anggota dapat menjadi pendukung penguatan kapasitas kelembagaan. Lemahnya kepercayaan dalam KTT di Kelurahan Kumpulrejo menjadi fenomena baru dalam keterkaitan modal sosial di daerah yang masih erat dengan ciri masyarakat pedesaan, karena secara umum masyarakat pedesaan biasanya memiliki kepercayaan yang terbilang tinggi antarindividu.

Tabel 3. Hasil Analisis Pengaruh Kepercayaan terhadap Penguatan Kapasitas Kelembagaan

\begin{tabular}{lrr}
\hline \multicolumn{3}{c}{ Coefficients $^{\mathbf{a}}$} \\
\hline \multicolumn{1}{c}{ Model } & t & Sig. \\
\hline (Constant) &, 032 &, 975 \\
KEPERCAYAAN (X1) &, 799 &, 428 \\
\hline a. Dependent Variable: PENGUATAN KAPASITAS KELEMBAGAAN &
\end{tabular}

a. Dependent Variable: PENGUATAN KAPASITAS KELEMBAGAAN

Berdasarkan hasil penelitian terindikasi bahwa rendahnya intensitas pertemuan antaranggota kelompok dan kurangnya kegiatan internal maupun kegiatan eksternal yang diadakan atau diikuti oleh KTT menjadi penyebab buruknya kualitas interaksi soial antaranggota kelompok maupun pengurus yang dapat menjadikan rasa percaya antaranggota rendah. Hal tersebut juga mengindikasi bahwa pengurus KTT kurang aktif dalam melibatkan anggotanya di kegiatan-kegiatan pengembangan, sehingga mengakibatkan anggota kurang peduli dengan keberlanjutan kelompoknya. Kholifa (2016), menyatakan bahwa kepercayaan dapat terbentuk dengan meningkatkan intensitas bertemu dan kualitas interaksi sosial anggota karena hubungan sosial yang terjalin dalam waktu yang lama dapat menumbuhkan dan meningkatkan perasaan percaya antarindividu dalam suatu kelompok.

\section{Pengaruh Jejaring Sosial terhadap Penguatan Kapasitas Kelembagaan KTI di Kelurahan Kumpulrejo}

Analisis pengaruh jejaring sosial terhadap penguatan kapasitas kelembagaan pada Tabel 4 menunjukkan hasil bahwa secara parsial diperoleh nilai koefisien regresi sebesar 0,344. Pada taraf signifikansi $5 \%$ diperoleh nilai $t_{\text {hitung }} 3,141$ dan nilai signifikansi 0,003 , dikarenakan nilai signifikansi $<0,05$, maka dapat ditarik kesimpulan bahwa jejaring sosial anggota KTT berpengaruh secara signifikan terhadap penguatan kapasitas kelembagaan, 
artinya semakin tinggi nilai jejaring sosial maka semakin tinggi pula penguatan kapasitas kelembagaan KTT di Kelurahan Kumpulrejo.

Tabel 4. Hasil Analisis Pengaruh Jejaring Sosial terhadap Penguatan Kapasitas Kelembagaan

\begin{tabular}{l|r|r}
\hline \multicolumn{3}{c}{ Coefficients $^{\mathbf{a}}$} \\
\hline \multicolumn{1}{c|}{ Model } & \multicolumn{1}{c}{ t } & \multicolumn{1}{c}{ Sig. } \\
\hline (Constant) &, 032 &, 975 \\
JEJARING SOSIAL (X2) & 3,141 &, 003 \\
\hline
\end{tabular}

a. Dependent Variable: PENGUATAN KAPASITAS KELEMBAGAAN

Jejaring sosial sebagai keterkaitan dalam kehidupan sosial yang terjadi antaranggota mendorong rasa saling asah, asuh, dan asih antaranggota dalam berusaha ternak (Amin, 2016). Dalam mempererat hubungan kekeluargaan antaranggota, KTT rutin mengadakan pertemuan rutin dan juga kerja bakti. Jejaring eksternal KTT dijalin dengan membentuk kerjasama dengan pihak luar seperti dalam pengolahan maupun pemasaran produk susu sapi. Dalam hal ini, Kelompok Wanita Tani (KWT) Sukasari menjadi mitra penopang dalam pengolahan susu sapi menjadi berbagai produk olahan seperti keju mozarella, keju halloumi, ice cream maupun yogurt, namun untuk saat ini pengolahan susu hanya dilakukan ketika ada event tertentu. Beberapa kegiatan KWT dapat dilihat pada Gambar 3.

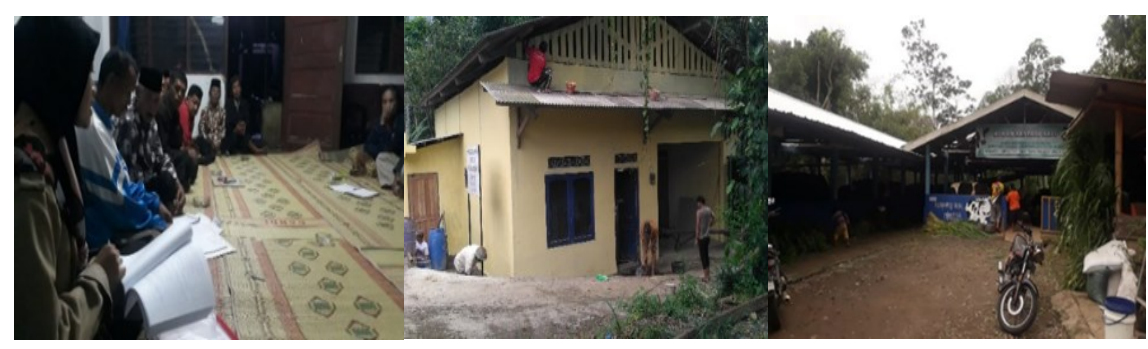

\section{Gambar 3. Kegiatan Pertemuan Rutin dan Kegiatan Kerjabakti KTT di Kelurahan Kumpulrejo}

\section{Pengaruh Norma terhadap Penguatan Kapasitas Kelembagaan KTT di Kelurahan Kumpulrejo}

Norma merupakan nilai-nilai atau aturan yang bertujuan sebagai pengendali tingkah laku dan arah tujuan suatu kelompok sehingga lebih terorganisir. Adapun analisis pengaruh norma terhadap penguatan kapasitas kelembagaan KTT di Kelurahan Kumpulrejo, dapat dilihat pada Tabel 5.

Tabel 5 menunjukkan hasil bahwa secara parsial diperoleh nilai koefisien regresi sebesar 0,470 . Pada taraf signifikansi $5 \%$ diperoleh nilai $t_{\text {hitung }} 4,258$ dan nilai signifikansi 0,000 , dikarenakan nilai signifikansi $<0,05$, maka dapat ditarik kesimpulan bahwa nilai norma anggota KTT berpengaruh yang signifikan terhadap penguatan kapasitas kelembagaan, semakin tinggi nilai norma maka akan semakin tinggi pula penguatan kapasitas kelembagaan KTT di Kelurahan Kumpulrejo.

Norma menjadi sarana untuk membatasi adanya eksploitasi dalam pemanfaatan potensi lokal dan menjadi aturan yang dinilai efektif dalam mengelola suatu institusi (Anggraini \& Agus, 2018). Dalam penelitian ini didapati bahwa norma muncul karena adanya interaksi dalam kelompok, perkumpulan individu dalam sebuah kelompok pasti membutuhkan norma sebagai tata aturan pergaulan atau perilaku untuk menuntun individu dalam upaya mencapai keadaan atau suasana yang saling diinginkan dalam suatu 
kelompok, hasil penelitian menunjukkan bahwa norma yang dimiliki KTT di Kelurahan Kumpulrejo sudah terbentuk, namun belum sepenuhnya dipatuhi oleh setiap individu dalam kelompok serta belum adanya ketegasan dalam pelaksanaannya. Hal tersebut ditunjukan dengan belum terealisasinya peraturan pemberian sanksi kepada anggota yang secara berturut-turut tidak mengikuti pertemuan rutin kelompok, atau kegiatan lainnya dikarenakan rasa iba kepada anggota.

Tabel 5. Hasil Analisis Pengaruh Norma terhadap Penguatan Kapasitas Kelembagaan

\begin{tabular}{lrrr}
\hline & \multicolumn{3}{c}{ Coefficients $^{\mathbf{a}}$} \\
\hline Model & t & Sig. \\
\hline (Constant) & &, 032 &, 975 \\
NORMA (X3) & & 4,258 &, 000 \\
\hline
\end{tabular}

a. Dependent Variable: PENGUATAN KAPASITAS KELEMBAGAAN

\section{Pengaruh Modal Sosial terhadap Penguatan Kapasitas Kelembagaan KTT di Kelurahan Kumpulrejo}

Modal sosial merupakan hubungan antarmanusia yang didasari oleh rasa saling percaya dalam sekelompok individu atau masyarakat dalam jejaring sosial dan melahirkan suatu norma dan nilai yang disepakati oleh masyarakat tersebut dan berdasar pada rasa saling percaya. Umumnya masyarakat yang tinggal di daerah pedesaan cenderung memiliki indeks modal sosial yang lebih tinggi dibandingkan dengan masyarakat yang berada di daerah perkotaan. Perbedaan masyarakat desa dapat dilihat dari ciri khasnya yaitu sistem kehidupannya cenderung berkelompok berdasarkan pada sistem kekeluargaan. Hal tersebut berkebalikan dengan masyarakat kota yang umumnya cenderung lebih individualistis (Kholifa 2016). Kelurahan Kumpulrejo juga masih sangat erat dengan suasana pedesaan. Karakter masyarakat yang masih memegang teguh gotong-royong, menjalin kerukunan dan menjunjung tinggi nilai sosial dan agama, bahkan modal sosial berupa kepercayaan, jejaring sosial, dan norma yang dimiliki KTT di Kelurahan Kumpulrejo, telah melekat secara alamiah dalam diri mereka. Kondisi tersebut juga didukung dengan kondisi lingkungan dan sosial tempat tinggal mereka. Adapun kategorisasi modal sosial KTT di Kelurahan Kumpulrejo, dapat dilihat pada Tabel 6. Berdasarkan pada analisis yang telah dilakukan maka sumbangsih variabel kepercayaan, jejaring sosial, dan norma terhadap penguatan kapasitas kelembagaan KTT, dirangkum dalam Tabel 7.

Berdasarkan Tabel 6 dan Tabel 7, menunjukkan bahwa kepercayaan KTT di Kumpulrejo memiliki sumbangan efektif sebesar 3\% dan sumbangan relatif sebesar 5\%. Kepercayaan KTT berada dalam tingkat kategori sedang dengan persentase sebesar $76,7 \%$. Unsur kedua yaitu jejaring sosial KTT memiliki sumbangan efektif sebesar $22 \%$ dan sumbangan relatif sebesar 39\%. Jejaring sosial KTT berada dalam kategori sedang dengan persentase sebesar $73,3 \%$. Sementara itu norma KTT memiliki sumbangan efektif sebesar $32 \%$ dan sumbangan relatif sebesar $57 \%$. Norma KTT berada dalam tingkat kategori sedang dengan persentase sebesar $63,3 \%$.

Dilihat dari Tabel 7, ketiga unsur modal sosial berupa kepercayaan, jejaring sosial, dan norma KTT masih perlu ditingkatkan. Kepercayaan antaranggota kelompok dapat ditingkatkan dengan memperbaiki kualitas interaksi sosial antaranggota dengan menanamkan sifat jujur disetiap individu, jujur dalam kondisi apapun, karena kejujuran merupakan prinsip utama dalam membangun kepercayaan. Sementara itu, peningkatan jejaring sosial antaranggota kelompok dapat dilakukan dengan cara meningkatkan intensitas pertemuan anggota kelompok, seperti pertemuan rutin maupun kerja bakti. Membentuk jejaring sosial internal kelompok dapat dilakukan dengan merangkul, 
mendorong, serta membimbing seluruh anggota kelompok untuk dapat bekerjasama secara berkelompok, kemudian memperluas jejaring eksternal dapat dilakukan melalui jalinan kerjasama dengan pihak-pihak terkait. Selanjutnya, meningkatkan ketaatan terhadap norma dapat dilakukan dengan menumbuhkan rasa saling percaya karena berawal dari rasa percaya, anggota kelompok akan mematuhi peraturan dengan sukarela serta kelompok akan lebih terorganisir.

Tabel 6. Kategorisasi Kepercayaan, Jejaring Sosial, Norma, dan Penguatan Kapasitas Kelembagaan KTT

\begin{tabular}{lrrrrrrc}
\hline \multirow{2}{*}{ Variabel } & \multicolumn{9}{c}{ Kategorisasi } & \multirow{2}{*}{ Ket } \\
\cline { 2 - 8 } & Rendah & \% & Sedang & \% & Tinggi & \% & \\
\hline Kepercayaan & $<35$ & 6,7 & $35-41$ & 76,7 & $>41$ & 16,7 & Sedang \\
Jejaring Sosial & $<33$ & 8,3 & $33-40$ & 73,3 & $>40$ & 18,3 & Sedang \\
Norma & $<34$ & 15 & $34-40$ & 63,3 & $>40$ & 21,7 & Sedang \\
Penguatan Kapasitas Kelembagaan & $<81$ & 10 & $81-99$ & 68,3 & $>99$ & 21,7 & Sedang \\
\hline
\end{tabular}

Tabel 7. Rangkuman Sumbangan pada Masing-masing Variabel

\begin{tabular}{c|r|r|r|r|r}
\hline Variabel & \multicolumn{1}{|c|}{$\mathbf{R}^{\mathbf{2}}$} & \multicolumn{1}{c|}{ SE } & \multicolumn{1}{c|}{ SR } & \multicolumn{1}{c}{ \%SE } & \multicolumn{1}{c}{ \%SR } \\
\hline Kepercayaan & & 2,63 & 4,54 & $3 \%$ & $5 \%$ \\
Jejaring Sosial & \multirow{3}{*}{57,9} & 22,32 & 38,55 & $22 \%$ & $39 \%$ \\
Norma & & 32,99 & 56,98 & $32 \%$ & $57 \%$ \\
Jumlah & & & & $57,9 \%$ & $100 \%$ \\
\hline
\end{tabular}

Analisis pengaruh modal sosial terhadap penguatan kapasitas kelembagaan, dari hasil analisis regresi liner berganda pada Tabel 8 menunjukkan bahwa secara simultan modal sosial memiliki pengaruh yang signifikan terhadap penguatan kapasitas kelembagaan. Hal ini ditunjukan dengan pengujian uji $\mathrm{F}$ secara simultan dengan perolehan

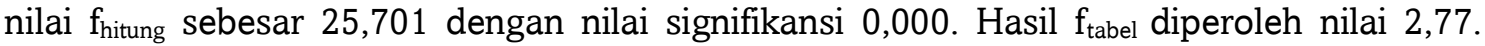
Berdasarkan perhitungan tersebut maka variabel $X$ secara simultan berpengaruh terhadap variabel $Y$ jika nilai sigifikansi $<0,05$ atau nilai $f_{\text {hitung }}>f_{\text {tabel }}$. Hasil pengujian analisis regresi berganda menunjukkan bahwa nilai koefisien determinasi sebesar 0,579 atau 57,9\% penguatan kapasitas kelembagaan dipengaruhi oleh variabel kepercayaan, jejaring sosial, dan norma sosial. Sedangkan 42,1\% lainnya dipengaruhi oleh variabel lain diluar variabel yang diteliti.

KTT sebagai institusi lokal memiliki kedudukan penting dalam pencapaian pembangunan kelurahan berkelanjutan di Kelurahan Kumpulrejo, melalui modal sosial yang secara alami telah tertanam dalam masyarakat. Fathy (2019), dalam penelitiannya mengungkapkan bahwa modal sosial memiliki peran dalam seluruh aspek pembangunan karena modal sosial menitik beratkan pada pentingnya menjaga jalinan hubungan dan rasa saling percaya antarindividu. Modal sosial sebagai naluri alamiah yang tumbuh dan berkembang dalam kelompok dapat memberikan manfaat positif bagi keberlangsungan kelompok. Sebaliknya, modal sosial yang tidak dilestarikan dapat menyebabkan melemahnya modal sosial tersebut. Hal tersebut ditandai dengan adanya ketegangan hubungan antaranggota kelompok, pelanggaran terhadap norma, tidak adanya keadilan dan kesetaraan, tidak adanya transparansi, rendahnya partisipasi/keikutsertaan anggota. Apabila hal tersebut dibiarkan maka akan mengakibatkan hilangnya kepercayaan, kebersamaan, dan terancamnya eksistensi kelembagaan KTT.

Sementara itu, tingkat penguatan kapasitas kelembagaan KTT di Kelurahan Kumpulrejo berada dalam kategori sedang yaitu dengan frekuensi 41 responden dan persentase sebesar $68,3 \%$. Pada tingkatan individu berada pada kategori sedang dengan 
pesentase jawaban $63,3 \%$, tingkatan organisasi juga berada pada kategori sedang dengan persentase jawaban $66,7 \%$, serta pada tingkatan sistem juga berada pada kategori sedang dengan persentase jawaban $70 \%$. Hal tersebut dapat diartikan bahwa KTT di Kelurahan Kumpulrejo telah memiliki upaya untuk memperkuat kelembagaannya dalam aspek pengembangan sumber daya manusia; manajemen organisasi; serta sistem secara makro, akan tetapi belum optimal dalam pelaksanaannya.

Tabel 8. Hasil Analisis Pengaruh Modal Sosial Terhadap Penguatan Kapasitas Kelembagaan

\begin{tabular}{|c|c|c|c|c|c|}
\hline \multicolumn{6}{|c|}{ ANOVA $^{a}$} \\
\hline Model & Sum of Squares & Df & Mean Square & $\mathbf{F}$ & Sig. \\
\hline Regression & 2379,501 & 3 & 793,167 & 25,701 &, $000^{b}$ \\
\hline
\end{tabular}

Salah satu masalah yang menghambat berkembangnya usaha tani yaitu tingkat peran serta dari kelompok tani cenderung rendah dalam berbagai program pengembangan usaha tani yang diadakan oleh pemerintah dikarenakan tingkat kapasitas kelembagaan kelompok tani yang masih rendah (Ruhimat, 2017; Syahyuti, 2011). Hasil penelitian menunjukkan bahwa sebagian KTT di Kelurahan Kumpulrejo masih kurang dalam hal administratif dan terdapat kelompok tani yang dibentuk atas dasar iseng atau sekedar ingin memperoleh bantuan dari pemerintah. Hal tersebut menunjukkan bahwa tingkat kapasitas kelembagaan pada tingkatan individu, tingkatan organisasi, maupun tingkatan sistem KTT masih perlu dioptimalkan lagi.

Upaya memperkuat kapasitas kelembagaan KTT, telah dilakukan dengan mengikuti pelatihan dan pendampingan rutin oleh Dinas Pertanian maupun oleh pihak terkait lainnya. Dalam rangka pengembangan kapasitas kelembagaan metode yang dirancang difokuskan untuk mengubah individu dalam institusi menjadi individu yang berkeahlian, berpengetahuan, dan memiliki sikap yang baik guna memperkuat organisasi tersebut (Andi Samsu Alam \& Prawitno, 2015). Dari hasil penelitian, KTT Margo Raharjo IV menjadi satusatunya KTT di Kota Salatiga yang memperoleh pendampingan dari New Zeland dalam rangka kerjasama Indonesia Diary Excellence Activity (IDEA). Para peternak di KTT Margo Raharjo IV mendapat pendampingan berupa cara menanam rumput untuk pakan sapi, cara pembuatan silase (pakan pengganti hijauan), dan cara mengolah pakan konsentrat. Dari hasil pendampingan, KTT Margo Raharjo IV dapat memproduksi pakan konsentrat untuk ternak mereka dan untuk dijual secara luas. Sementara itu, KTT Rukun Santoso Satu memiliki pengelolaan kandang komunal yang cukup baik. Kandang komunal yang dimiliki KTT Rukun Santoso, telah mulai dikunjungi oleh Sekolah Taman Kanak-kanak untuk melakukan wisata edukasi mengenai peternakan sapi perah.

KTT Margo Raharjo IV dan Rukun Santoso Satu menjadi contoh dari keberhasilan KTT di Kelurahan Kumpulrejo. Sementara itu, KTT lain masih memerlukan dukungan lebih untuk menjadi pendukung tercapainya kelurahan berbasis agrowisata di Kelurahan Kumpulrejo. Penguatan kapasitas kelembagaan KTT semakin menjadi hal yang harus perhatikan, melihat belum meratanya kegiatan pengembangan usaha tani ternak di Kelurahan Kumpulrejo.

\section{Pembangunan Kelurahan Berkelanjutan Berbasis Agrowisata}

Pembangunan kelurahan berkelanjutan berbasis agrowisata di Kelurahan Kumpulrejo merupakan upaya pembangunan dari tingkat basis yang dilakukan dengan menggali dan mengidentifikasi potensi, dalam hal ini adalah peternakan sapi perah, serta permasalahan yang terdapat pada ruang lingkup kelurahan. Selanjutnya hasil pemetaan tersebut menjadi 
bahan landasan untuk menyusun strategi dalam mengembangkan potensi wilayah dengan menilik aspek yang terdapat pada Sustainable Development Goal's, dengan tujuan utamanya adalah untuk mensejahterakan kehidupan masyarakat. Dalam pembangunan kelurahan berkelanjutan berbasis agrowisata, Kelurahan Kumpulrejo mendapat pendampingan dari Fakultas Ilmu Sosial dan Ilmu Komunikasi, Universitas Kristen Satya Wacana, dan pendampingan dari Badan Perencanaan dan Pembangunan Daerah (Bappeda) dalam peyusunan strategi serta sebagai sarana koordinasi pada dinas-dinas terkait dalam mengintgrasikan kebijakan agar sejalan dan saling bersinegi. Berdasarkan hasil perhitungan dan pengolahan data oleh Bappeda dan Fakultas Ilmu Sosial dan Ilmu Komunikasi, menunjukkan bahwa indikator $S G D$ 's di Kelurahan Kumpulrejo mencapai target sebesar 33\% (14 indikator) dari total 42 indikator yang dapat mendukung pencapaian Sustainable Development Goals (SGDs) di tingkat Kota Salatiga.

Sehubungan dengan hal itu, Lurah Kumpulrejo berencana merealisasikan rencananya dalam membangun kelurahan berkelanjutan berbasis peternakan yang dibungkus dengan arah menuju kelurahan wisata dengan mengedepankan potensi lokalnya yaitu susu sapi. Terkait hal tersebut, pengembangan Kelurahan Kumpulrejo yang berbasis agrowisata akan diintegrasikan dalam program yang didanai oleh Dana Alokasi Umum Tambahan (DAUT) Kelurahan, yang lazim dikenal dengan istilah Dana Kelurahan. Gagasan tersebut menjadi sarana unggulan untuk menyeimbangkan aspek sosial, ekonomi, lingkungan, dan budaya di Kelurahan Kumpulrejo yang selaras dengan asas Tujuan Pembangunan Berkelanjutan.

\section{Kesimpulan}

Pembangunan Kelurahan Berkelanjutan berbasis potensi lokal menjadi terobosan baru dalam pencapaian aspek tujuan pembangunan berkelanjutan di tingkat basis yang dilakukan oleh Pemerintah Kota Salatiga. Kelurahan Kumpulrejo sebagai prioritas utama Pemerintah Kota Salatiga dalam hal ini telah berhasil memetakan potensi dalam sektor peternakan dan telah melakukan upaya persiapan diri sebagai Kelurahan Agrowisata. Kelembagaan KTT sebagai aktor utama yang berpotensi dalam realisasi pembangunan kelurahan berkelanjutan berbasis agrowisata memiliki kapasitas sebagai pendukung terciptanya tujuan tersebut meskipun belum optimal, namun modal sosial yang dimiliki KTT secara umum dapat menjadi aset pendukung penguatan kapasitas kelembagaan KTT di Kelurahan Kumpulrejo terlebih karena masyarakatnya yang masih bercirikan masyarakat pedesaaan. Meskipun unsur modal sosial berupa kepercayaan memiliki pengaruh yang tidak signifikan terhadap penguatan kapasitas kelembagaan KTT karena kurang adanya keterbukaan dalam kelompok, namun unsur jejaring sosial dan norma memiliki pengaruh yang signifikan terhadap penguatan kapasitas kelembagaan KTT.

Penelitian ini telah berhasil mengidentifikasi kapasitas kelembagaan di tingkat kelurahan yang masih erat dengan suasana pedesaan beserta modal sosial yang dimiliki sebagai pendukung tercapainya Tujuan Pembanguan Bekelanjutan di tingkat basis. Namun demikian, pembangunan kelurahan berkelanjutan berbasis agrowisata di Kelurahan Kumpulrejo saat ini masih memerlukan kajian lebih dalam, melihat masih belum optimalnya kapasitas kelembagaan KTT di Kelurahan Kumpulrejo. Dalam pencapaiannya, perlu diperkuat pola hubungan kerjasama antar pemangku kepentingan yaitu KTT, Pemerintah Daerah, maupun pihak terkait lainnya, serta program upaya penguatan kapasitas kelembagaan KTT harus dilakukan secara merata sehingga tidak hanya terfokus pada satu atau dua kelompok saja. Pembangunan wilayah yang berorientasi pada pemanfaatan potensi lokal secara optimal dan mengembangkan kemampuan masyarakat, dapat menjadi dasar penting dalam pencapaian tujuan pembangunan berkelanjutan. 


\section{Penguatan Kapasitas Kelembagaan dalam Pembangunan Kelurahan Berkelanjutan . . .}

\section{Daftar Pustaka}

Amin, S. (2016). Pengaruh unsur modal sosial terhadap keberhasilan kelompok tani-ternak penerima bantuan program sarjana membangun desa (SMD) di Kabupaten Bone. Universitas Hassanudin.

Andi Samsu Alam, \& Prawitno, A. (2015). Pengembangan kapasitas organisasi dalam peningkatan kualitas pelayanan publik Dinas Kehutanan dan Perkebunan Kabupaten Bone. Government:Jurnal Ilmu Pemerintahan, 8(2), 93-104.

Anggraini, O., \& Agus, M. (2018). Penguatan modal sosial berbasis kelembagaan lokal masyarakat pesisir perspektif gender di Kabupaten Bantul. Journal of Social and Agricultural Economics, 11(2), 11-24. doi:10.19184/jsep.v11i2.6889.

BPS Kota Salatiga. (2020). Kota Salatiga dalam angka 2020. Salatiga.

Daryanto, A. (2009). Dinamika daya saing industri peternakan. Bogor: IPB Press.

Dinas Pertanian Kota Salatiga. (2018). Buku saku dinas pertanian Kota Salatiga tahun anggaran 2019. Salatiga.

Fathy, R. (2019). Modal sosial: Konsep, inklusivitas dan pemberdayaan masyarakat. Jurnal Pemikiran Sosiologi, 6(1), 1-17. doi:10.22146/jps.v6i1.47463.

Fitriani, F. (2015). Penguatan kapasitas kelembagaan gapoktan melalui pembentukan koperasi pertanian. Masyarakat, Kebudayaan dan Politik, 28(2), 63-69. doi:10.20473/mkp.V28I22015.65-71.

Fukuyama, F. (1995). Trust: The social virtues and the creation of prosperity. New York: Free Press.

Gefen, D., Karahanna, E., \& Straub, D. W. (2003). Trust and TAM in online shopping: An integrated model. MIS Quarterly, 271), 51-90. doi:10.2307/30036519.

Hadiwijoyo, S. S., \& Anisa, F. D. (2019). SDGs, paradigma baru pembangunan global. Yogyakarta: Sprektrum Nusantara.

Kadarisman, M. (2017). Pengembangan sumber daya manusia. Jakarta: PT Raja Grafindo Persada.

Kholifa, N. (2016). Pengaruh modal sosial terhadap produktivitas petani (Studi kasus di Kecamatan Cilacap Utara Kabupaten Cilacap). Jurnal Pendidikan dan Ekonomi, 5(2), 89-97.

Kim, D., \& Benbasat, I. (2003). Trust-related arguments in internet stores: A framework for evaluation. Journal of Electronic Commerce Research, 4(2), 49-64.

Lawang, R. M. Z. (2004). Kapital sosial: dalam perspektif sosiologik suatu pengantar. Depok: FISIP-UI Press.

Milen, A. (2004). Pegangan dasar pengembangan kapasitas. Yogyakarta: Pondok Pustaka Jogja.

Pratama, A., Muchammad, M., \& Djumiarti, T. (2014). Pengembangan kapasitas kelembagaan dalam koordinasi pelayanan perizinan di BPPT Semarang. Journal of Public Policy and Management Review, 3(1), 1-11. doi:10.14710/jppmr.v3i1.4373.

Rizki, D. M. (2015). Pengembangan kapasitas (capacity building) kelembangaan daerah dalam meningkatkan kualitas pelayanan publik di era revolusi industri 4.0 pada Dinas Penanaman Modal dan Pelayanan Terpadu Satu Pintu (DPMPTS) Kabupaten Ciamis. Universitas Galuh.

Ruhimat, I. S. (2017). Peningkatan kapasitas kelembagaan kelompok tani dalam pengembangan usahatani agroforestry: Studi kasus di Desa Cukangkawung, Kecamatan Sodonghilir, Kabupaten Tasikmalaya, Provinsi Jawa Barat. Jurnal Penelitian Sosial dan Ekonomi Kehutanan, 14(1), 1-17. doi:10.20886/jpse.2017.14.1.1-17.

Seran, Y. L., \& Kote, M. (2007). Strategi penguatan kelembagaan secara partisipatif sebagai solusi terhadap kesenjangan partisipasi stakeholders (Kasus Prima Tani Desa Tobu - TTS). BPTP NTT.

Simatupang, R. A. (2017). Pengaruh kepercayaan, kepuasan konsumen, dan nilai terhadap loyalitas produk. Jurnal Riset Manajemen dan Bisnis, 12(1), 55-70.

Soeprapto, T. (2006). Penguatan kapasitas dengan sumber daya manusia. Yogyakarta: Media Pressindo.

Subekti, S., Sudarko, S., \& Sofia, S. (2015). Penguatan kelompok tani melalui optimalisasi dan sinergi lingkungan sosial. Journal of Social and Agricultural Economics, 8(3), 50-56. Retrieved from https://jurnal.unej.ac.id/index.php/JSEP/article/view/3760.

Suyitman, S., Sutjahjo, S. H., Herison, C., \& Muladno, N. (2016). Status keberlanjutan wilayah berbasis peternakan di Kabupaten Situbondo untuk pengembangan kawasan agropolitan. Jurnal Agro Ekonomi, 272), 165. doi:10.21082/jae.v27n2.2009.165-191. 
Syahra, R. (2003). Modal sosial: Konsep dan aplikasi. Jurnal Masyarakat Dan Budaya.

Syahyuti, S. (2011). Gampang-gampang susah mengorganisasikan petani. Bogor: IPB Press.

Triambodo, S. \& D. (2015). Analisis strategi penguatan kelembagaan desa wisata berbasis ekonomi kreatif (studi di Desa Wisata Kerajinan Tenun Dusun Gamplong, Desa Sumberrahayu, Kecamatan Moyudan, Kabupaten Sleman, DIY). Universitas Gadjah Mada. 